\title{
Joint Probabilistic Analysis of Risk for Aquatic Species and Exceedence Frequency for the Agricultural Use of Chlorpyrifos in the Pampean Region, Argentina
}

\author{
Melina Alvarez, ${ }^{a}$ Cecile Du Mortier, ${ }^{a}$ Soledad Jaureguiberry, ${ }^{b}$ and Andrés Venturino ${ }^{b, *}$ \\ ${ }^{a}$ Centro de Estudios Transdisciplinarios del Agua-Investigaciones en Producción Animal, Facultad de Ciencias Veterinarias, Universidad de Buenos Aires, Buenos Aires, \\ Argentina

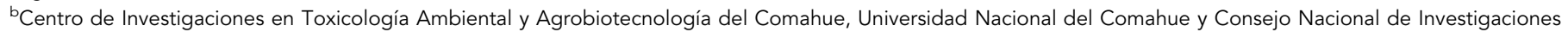 \\ Científicas y Técnicas, Buenos Aires and Neuquén, Argentina
}

Abstract: The Pampa Húmeda region in Argentina is characterized by soybean, wheat, and maize production, with intensive application of agrochemicals such as herbicides and insecticides. We used a joint probabilistic approach to analyze the probabilities for environmental chlorpyrifos concentrations measured in the Pampa Húmeda to exceed acute or chronic hazardous concentration for $5 \%$ of the species ( $\mathrm{HC} 5$ ) values estimated from species sensitivity distributions for aquatic species. Chlorpyrifos concentrations in water ranged from 0.0005 to $10.8 \mu \mathrm{g} / \mathrm{L}$, with a median of $0.013 \mu \mathrm{g} / \mathrm{L}$. The HC5 limits were $0.0637 \mu \mathrm{g} / \mathrm{L}$ for acute and $0.0007 \mu \mathrm{g} / \mathrm{L}$ for chronic effects. The probabilities for chlorpyrifos environmental concentrations to exceed the HC5 values ranged from 35\% (acute effects) to $96 \%$ (chronic effects). Water quality criteria (WOC) for the protection of aquatic life were also frequently exceeded (by 48-87\%) for both acute and chronic effects. Together with published threshold limit values from mesocosm studies, these data suggest that macroinvertebrate communities can be severely affected by the reported environmental concentrations of chlorpyrifos. Indeed, changes in the macroinvertebrate assemblage in the Pampa Húmeda have been correlated with chlorpyrifos levels in sediments. Nevertheless, the actual impact needs to be ascertained by assessing the recovery rate of macroinvertebrate populations in this region. Considering the HC5 for chronic effects and the threshold limits for macroinvertebrate community level effects, we propose $0.7 \mathrm{ng} / \mathrm{L}$ as a new WQC to effectively protect aquatic life from long-term exposure to chlorpyrifos. Environ Toxicol Chem 2019;38:1748-1755. () 2019 SETAC.

Keywords: Acute toxicity; Aquatic life protection criteria; Chronic toxicity; Organophosphates; Pesticides; Species sensitivity distributions

\section{INTRODUCTION}

Over the last decades, agricultural activities in the Pampa Húmeda region in Argentina have undergone a remarkable expansion based on incorporation of transgenic crop technologies. The region supplies more than $80 \%$ of the national production of wheat, maize, and soy, which are mainly intended as export commodities (Rótolo et al. 2014). The intensification in crop productivity has been paralleled by increased use of agrochemicals, particularly herbicides and insecticides, which increased the environmental impact. Between 2012 and 2016 the agrochemical market in Argentina

This article includes online-only Supplemental Data.

* Address correspondence to a.venturino@conicet.gov.ar

Published online 15 April 2019 in Wiley Online Library

(wileyonlinelibrary.com).

DOI: $10.1002 /$ etc. 4441 registered a large increase in both herbicide volume and costs (from 64 to $87 \%$ ), as well as insecticide use (20 million kg; $\sim 400$ million USD). Chlorpyrifos (O,O-diethyl O-(3,5,5-trichloro2-pyridyl) phosphorothioate) was the leading insecticide in 2012, with an investment of 61 million USD ( 4.7 million $\mathrm{kg}$ of commercial product; Cámara de Sanidad Agropecuaria y Fertilizantes 2012, 2016).

In the United States, before changes were made in the use pattern of chlorpyrifos, high concentrations were frequently detected in water samples (Giesy et al. 1999; US Geological Survey 2000). After the changes, detection frequencies and 95th percentile concentrations decreased more than 5 -fold between 1992 and 2010 (Williams et al. 2014). The main sources of surface water contamination with chlorpyrifos are runoff, erosion, and tail waters (Giddings et al. 2014), followed by aerial drift and atmospheric deposition. Chlorpyrifos is one of the most commonly detected pesticides in surface and groundwater in 
agricultural regions in the Pampa Húmeda, where aerial application of this insecticide and other pesticides provides a pathway for contamination of nearby water courses (Mugni et al. 2011). However, despite a marked increase in its use, the potential impact of chlorpyrifos on Pampa Húmeda's biota has not been thoroughly assessed. Thus, we focused on published ecotoxicological and environmental data to perform a joint probability analysis of the impact of chlorpyrifos on aquatic species, and to determine whether levels exceed different water quality criteria (WOC) for aquatic life protection. In accordance with the higher tier aquatic risk assessment for pesticides guidance document (Campbell et al. 1999), species sensitivity distributions (SSDs) representative of the most sensitive taxonomic groups were used to estimate the hazardous concentration for $5 \%$ of the species ( $\mathrm{HC} 5$ ) and $10 \%$ of the species $(\mathrm{HC} 10)$ values as risk assessment endpoints. Using the higher tier approach, population-, micro/mesocosm-, or community-level effects were also analyzed to determine the ecological impact of chlorpyrifos (Direction Générale de la Santé et des Consommateurs, European Commission 2002). We propose that a new WOC threshold limit for chlorpyrifos of $0.7 \mathrm{ng} / \mathrm{L}$ should be set to protect aquatic life from long-term exposure.

\section{MATERIALS AND METHODS}

\section{Study area and environmental data search}

We selected environmental concentration data of chlorpyrifos in water from different streams and basins in the Pampa Húmeda region (Figure 1): the Tres Arroyos-Claromecó basin (Álvarez 2015); the El Sauce stream (Demetrio 2012); the El Crespo stream (Pérez et al. 2017); the Brown-Horqueta streams (Jergentz et al. 2005); the Pergamino-Paraná River basin (Marino and Ronco 2005); the Paraguay-Paraná Rivers basin (Ronco 2015); and the Suquía River (Bonansea et al. 2013). This data set included 24 sampling sites, with 2 to 9 campaigns/site, and a total of 193 different samples. Only environmental concentrations higher than the respective limits of detection (LODs) were considered for further analysis, given that values below the LOD do not necessarily imply zero product concentration. Detection frequencies ranged between 40 and $100 \%$ and are reported in the references just cited.

\section{Joint probability analysis of SSDs and exceedence of environmental concentrations of chlorpyrifos in water}

Exceedance probability assessment. Chlorpyrifos concentration data in the Pampa Húmeda were ranked in decreasing order. The rank was transformed to percentile values $[i /(n+1)]$, where $i$ is the ranking number and $n$ is the total number of data. Probit models were fitted to the percentile versus concentration data to estimate the exceedance probability distribution. One- and 2-rank (biphasic) distributions were fitted and statistically compared (Anguiano et al. 2014).

Toxicological data search and SSDs. We searched the literature for toxicological data (median effect concentration

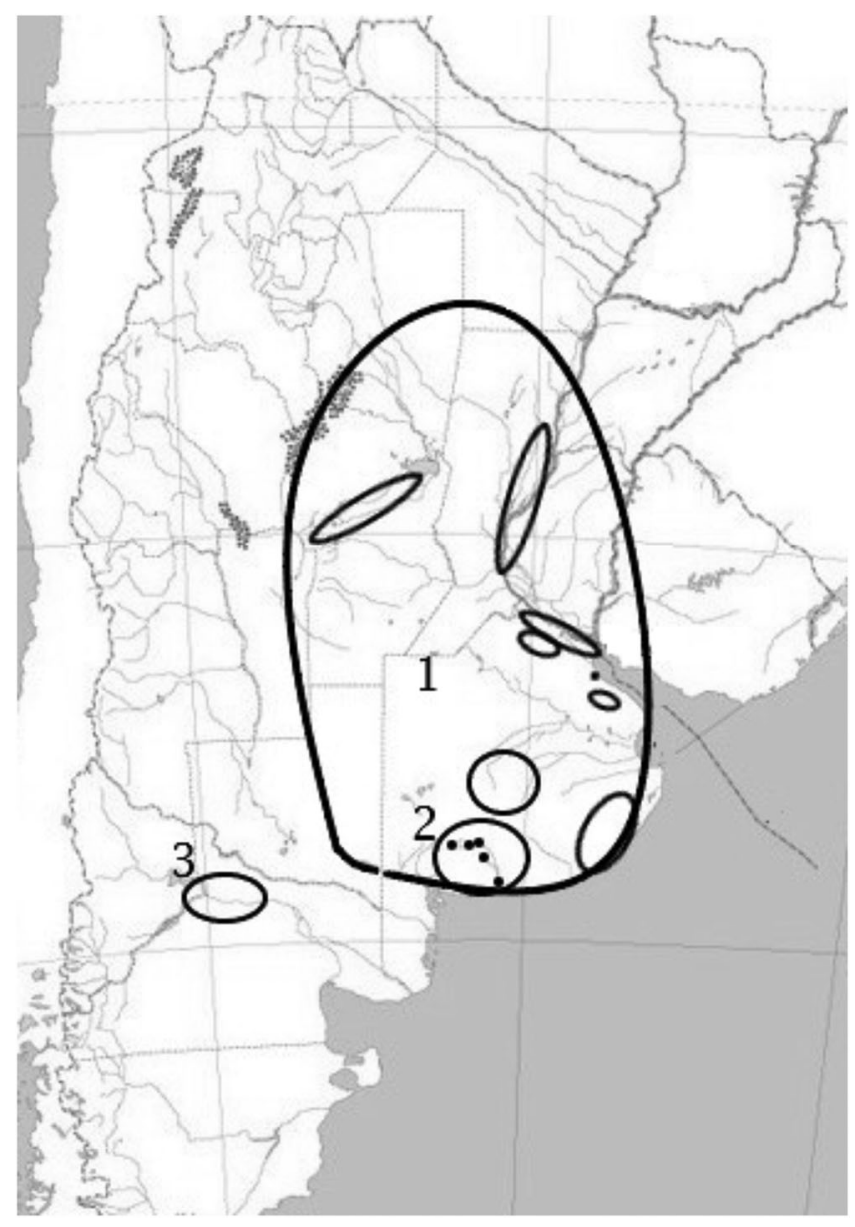

FIGURE 1: Sampling sites for determination of environmental concentrations of chlorpyrifos in Argentina. The largest area (1) is the Pampa Húmeda region, where transgenic soybeans are grown intensively; the area labeled (2) identifies 2-yr consecutive sampling at 5 sites in the Tres Arroyos-Claromecó basin, and other small areas correspond to the other sites referenced in the main text; (3) is the sampled zone in the Alto Valle de Río Negro y Neuquén (North Patagonia).

[EC50], lowest-observed-effect concentration [LOEC], and noobserved-effect concentration [NOEC]) describing short-term or long-term exposures of aquatic species to chlorpyrifos (Supplemental Data, Tables A and B). Quality criteria for data acceptance included accessible published work in a peer-reviewed international journal; thorough description of exposure conditions and methodology; inclusion of replicates; statistical analyses and setting of confidence limits to determine endpoints (model fitting or analysis of variance plus post hoc tests); ecotoxicologically relevant effects chosen for EC, LOEC, or NOEC; adequate range and series of exposure concentrations to determine effects; and endpoints covered by the experimental concentration ranges.

Species were ranked by decreasing sensitivity for acute effects (median lethal concentration [LC50]), and the rank was transformed to percentile values (Solomon et al. 1996; Ecological Committee on FIFRA Risk Assessment Methods 1999). Probit models were fitted to percentile rank versus logtransformed LC50 values to obtain the regression equations, considering 1- or 2-rank (biphasic) distributions (Anguiano et al. 


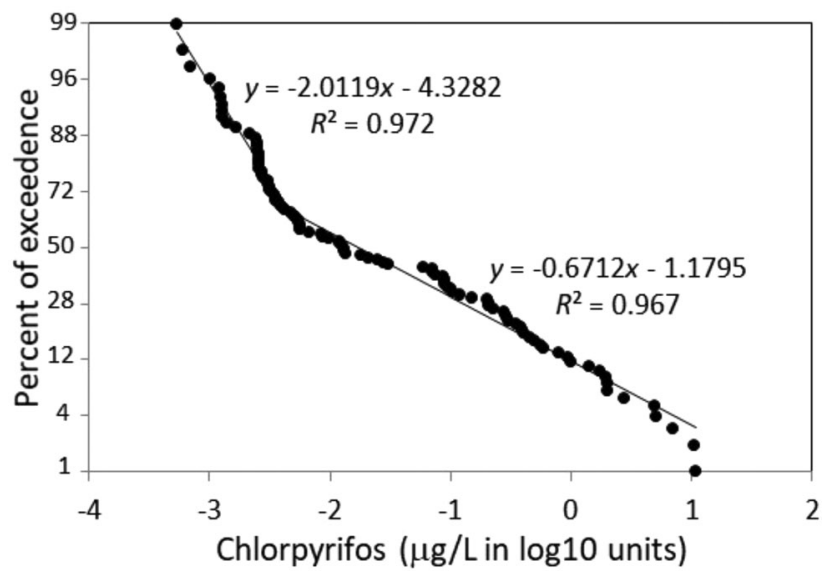

FIGURE 2: Exceedance probability analysis for environmental concentrations of chlorpyrifos in the Pampa Húmeda region. Environmental data and corresponding best-fitting bi-log-normal model are shown.

2014). We carried out the same procedure using EC, LOEC, and NOEC values from long-term exposures to assess SSDs for chronic risks of chlorpyrifos in aquatic species (chronic reproductive, developmental, or toxic effects). Hazard concentrations ( $\mathrm{HC} 5$ and $\mathrm{HC} 10$ ) were estimated from chlorpyrifos concentrations corresponding to the 5th and 10th percentiles, respectively.

Joint probability analysis. The probabilities for environmental chlorpyrifos levels to exceed the $\mathrm{HC} 5$ or $\mathrm{HC} 10$ values for acute and chronic effects in aquatic species were visualized in a combined graph and calculated from the respective model equations. We also estimated the percentages of species potentially affected by maximum and median chlorpyrifos environmental concentrations in the Pampa Húmeda.

\section{Compliance with regulatory standards}

We analyzed the probabilities that environmental concentrations of chlorpyrifos in Pampa Húmeda would exceed different WOC levels. Such levels included the most restrictive to date, namely, the WQC from Canada's regulatory legislation (Canadian Council of Ministers for the Environment 2008), as well as WQCs from Argentina (Subsecretaría de Recursos Hídricos de la Nación 2005), and other regions worldwide (US Environmental Protection Agency 1986; California Department of Fish and Game 2002; Palumbo et al. 2012; European Commission 2013; International Union of Pure and Applied Chemistry 2019).

\section{Higher tier estimation of chlorpyrifos impact in the Pampa Húmeda region}

We used published microcosm or mesocosm studies involving aquatic macroinvertebrates exposed to chlorpyrifos, either alone or with other insecticides, to compare the suggested community exposure limits with the environmental concentrations measured in the Pampa Húmeda region. Finally, we analyzed published data from field studies describing population- or
TABLE 1: Descriptive statistics of environmental concentrations of chlorpyrifos in water from different streams in the Pampa Húmeda $(N=102)^{\mathrm{a}}$

\begin{tabular}{lc}
\hline Statistic & Chlorpyrifos conc. \\
\hline Mean & 0.5897 \\
Median & 0.0130 \\
Minimum & 0.0005 \\
Maximum & 10.8 \\
Lower quartile & 0.0028 \\
Upper quartile & 0.0979 \\
Standard deviation & 1.7716 \\
\hline
\end{tabular}

${ }^{a}$ Data are expressed in $\mu \mathrm{g} / \mathrm{L}$. Only values above the limit of detection are included.

community-level effects attributed to chlorpyrifos and other insecticides found in water and sediment samples in this region.

\section{RESULTS}

\section{Distribution analysis of environmental chlorpyrifos concentrations in the Pampa Húmeda region}

We found similar distribution profiles for environmental levels of chlorpyrifos measured in different sites within the Pampa
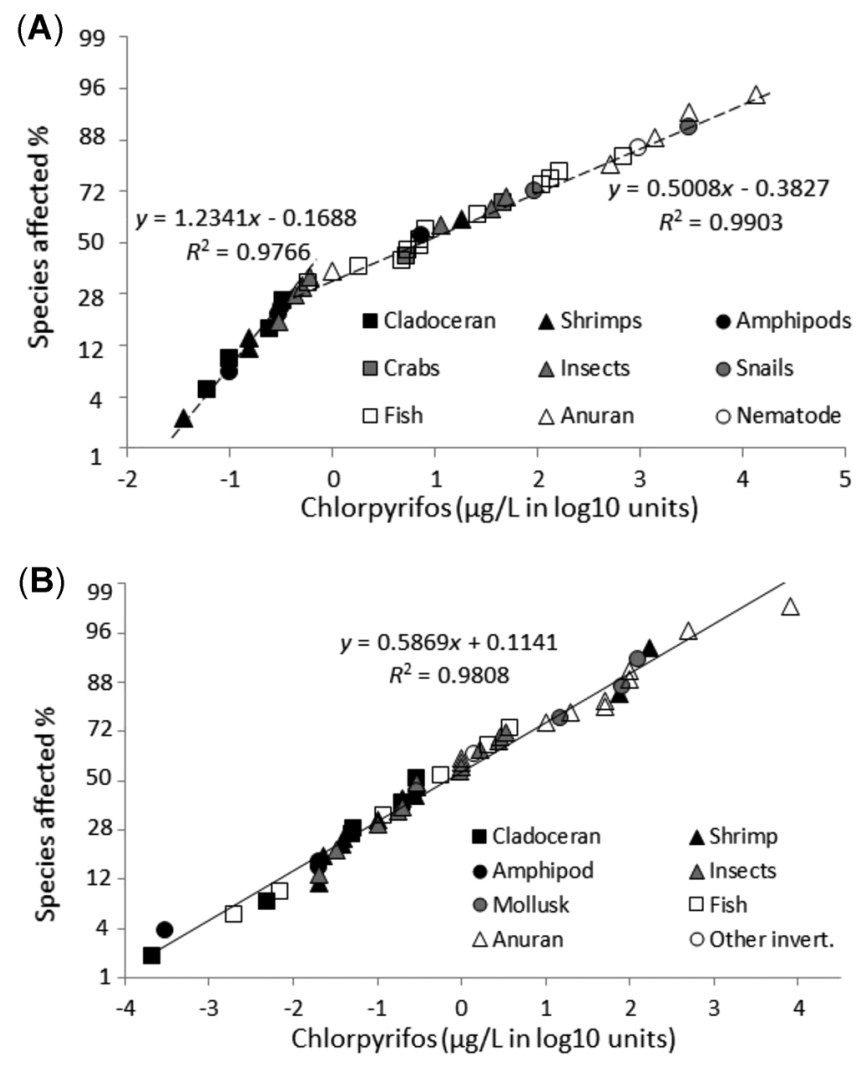

FIGURE 3: Species sensitivity distribution analysis for chlorpyrifos effects on aquatic organisms. (A) Median effect concentration (EC50) data and bi-log-normal probit model fitting for acute risk. (B) Noobserved-effect concentration/lowest-observed-effect concentration (NOEC/LOEC) data and probit model fitting for chronic effects. 
TABLE 3: Exceedance probabilities for environmental concentrations of chlorpyrifos in the Pampa Húmeda region in relation to different limit criteria

\begin{tabular}{lcc}
\hline Criteria & & $\%$ \\
\hline Species risk $^{a}$ & Acute HC5 SSD & 35.3 \\
& Acute HC10 SSD & 28.3 \\
& Chronic HC5 SSD & 95.6 \\
& Chronic HC10 SSD & 67.6
\end{tabular}

WQC for aquatic life protection $^{\mathrm{b}}$
Argentina $(0.006 \mu \mathrm{g} / \mathrm{L})$

62.2

Canada short term $(0.020 \mu \mathrm{g} / \mathrm{L}) \quad 48.4$ Canada long term $(0.002 \mu \mathrm{g} / \mathrm{L}) \quad 86.5$

European Union maximum $(0.1 \mu \mathrm{g} / \mathrm{L})$

European Union annual $(0.033 \mu \mathrm{g} / \mathrm{L})$

USEPA USA acute

$(0.08345 \mu \mathrm{g} / \mathrm{L})$

USEPA USA chronic

$(0.00562 \mu \mathrm{g} / \mathrm{L})$

California State maximum $(0.02 \mu \mathrm{g} / \mathrm{L})$

California State chronic $(0.014 \mu \mathrm{g} / \mathrm{L})$

UK acute $(0.01 \mu \mathrm{g} / \mathrm{L})$

UK chronic $(0.002 \mu \mathrm{g} / \mathrm{L})$

University of California Davis $(0.01 \mu \mathrm{g} / \mathrm{L})$ environmental data from Pampa Húmeda showed a biphasic distribution as the best probabilistic model match (Figure 2). The 2 differentiated ranges were not explained by site or date segregation (Supplemental Data, Table D, associated figure).

\section{SSD analyses for acute and chronic effects}

Our acute risk analysis discriminated by taxonomic groups indicated that shrimp, cladoceran, and amphipod species were most sensitive to chlorpyrifos, whereas other arthropods, but also mollusks and vertebrates, were affected at higher concentrations (Figure 3A). The SSD showed a biphasic distribution as the best probabilistic model, from which an acute HC5 of $0.064 \mu \mathrm{g} / \mathrm{L}$ was derived (Table 2).

The chronic effects distribution showed that the most sensitive species belonged to arthropod taxa (shrimps, cladocerans, amphipods, insects) and fish (Figure 3B). Anurans and mollusks showed lower sensitivity to chlorpyrifos for chronic effects, compared with the other groups. Probit model fitting to data resulted in a single log-normal distribution from which the $\mathrm{HC} 5$ was estimated as $0.0010 \mu \mathrm{g} / \mathrm{L}$ (Table 2). Probit fitting including only arthropod taxa (regression equation $y=0.7073 x$ +0.5951 ) did not substantially differ from the fitting to all species, with an estimated HC5 of $0.00068 \mu \mathrm{g} / \mathrm{L}$ (Supplemental Data, Table B, associated figure).

\section{Joint probability analysis}

Local species were evenly distributed along both acute and chronic SSDs (Figure 4). The most sensitive local species showed high frequencies of environmental concentrations of chlorpyrifos exceeding their LC50 or NOEC values at the Pampa Húmeda. The most sensitive local species corresponded to the cladocerans Ceriodaphnia dubia and Daphnia pulex, the shrimp Palaemonetes argentinus, and the fish Poecilia reticulata.

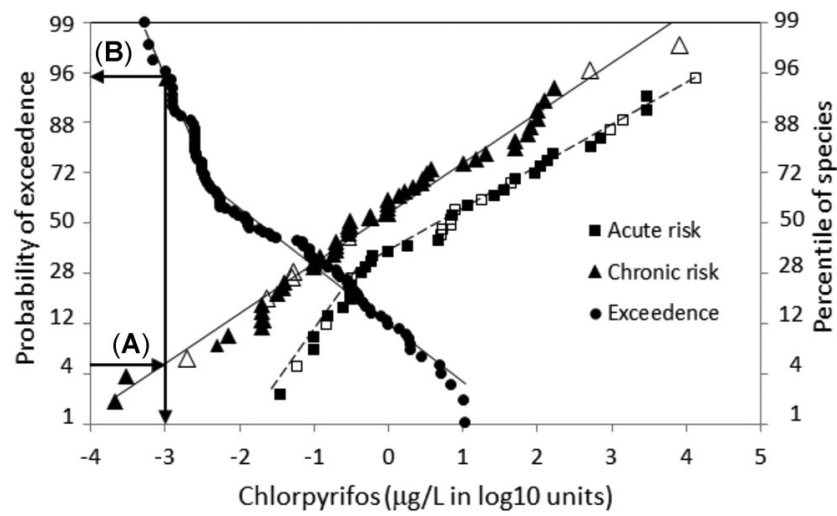

FIGURE 4: Joint probability analysis for chlorpyrifos. The exceedance probability model fitting (bi-log-normal) on the complete environmental dataset available for the Pampa Húmeda region and the acute and chronic species sensitivity distribution (SSD) curves are represented, with autochthonous and introduced species denoted by open symbols. As an example, the chronic hazardous concentration for $5 \%$ of the species $(\mathrm{HC} 5)$ value is shown $(\mathbf{A})$, corresponding to a concentration value of approximately $0.001 \mu \mathrm{g} / \mathrm{L}(\log \mathrm{c}=-3)$; this concentration is exceeded by nearly $96 \%$ of the environmental samples in Pampa Húmeda (B). 
The median environmental chlorpyrifos concentrations found in the Pampa Húmeda led to a $0.6 \%$ probability of acutely affected species (Table 2). In turn, the maximum chlorpyrifos concentrations matched with $55 \%$ of acutely affected species. On the other hand, 35\% of the water samples from this region had chlorpyrifos concentrations that exceeded the acute HC5 (Figure 4 and Table 3).

Regarding chronic risk, the median environmental concentrations of chlorpyrifos in the Pampa Húmeda matched with $16 \%$ of aquatic species affected, whereas a $76 \%$ match was found for maximal concentrations of the insecticide (Table 2). Ninety-six percent of the water samples from this region had chlorpyrifos concentrations exceeding the chronic HC5 (Figure 4 and Table 3).

\section{Compliance with WOC for aquatic life protection}

In $48 \%$ of instances, environmental chlorpyrifos concentrations in the Pampa Húmeda exceeded the most conservative WOC reference value for short-term exposures (Canadian Council of Ministers of the Environment 2008; Table 3). The exceedance probability for environmental chlorpyrifos concentrations with respect to the Canadian long-term exposure aquatic life protection criterion was $87 \%$. The Argentinean WQC limit was exceeded in $62 \%$ of cases. For other WQCs, chlorpyrifos concentrations showed lower exceeding percentages.

\section{Higher tier approach to chlorpyrifos potential impact in the Pampa Húmeda}

Next, chlorpyrifos exposure data was contrasted with community exposure limits for aquatic macroinvertebrates described in prior microcosm or mesocosm studies. We found that $30.6 \%$ of the water samples from the Pampa Húmeda exceeded the proposed limit of $0.1 \mu \mathrm{g} / \mathrm{L}$ required to protect aquatic ecosystems and macroinvertebrate communities (European Commission 2005; Table 4). Meanwhile, other proposed threshold concentrations showed higher probabilities (57-96\%) to be exceeded in the region.

\section{DISCUSSION}

The present study sought to evaluate the toxicological impact of chlorpyrifos, a neurotoxic organophosphate insecticide widely used for agricultural production, on aquatic organisms in the Pampa Húmeda region of Argentina. A probabilistic risk analysis of environmental concentrations of chlorpyrifos measured in 24 sampling sites from 7 water streams and river basins suggests that a significant number of aquatic species may be endangered by chlorpyrifos overuse. The chronic effects of chlorpyrifos are of concern, considering its high detection frequency in water samples (Jergentz et al. 2005; Marino and Ronco 2005; Bonansea et al. 2013; Álvarez 2015) at concentration levels exceeding the chronic HC5 value (96\% of the cases), and the likelihood of repeated seasonal exposures of the aquatic biota (Jergentz et al. 2005; Marino and Ronco 2005).

The bi-log-normal distribution observed for environmental chlorpyrifos concentrations in the Pampa Húmeda may be the result of different sampling approaches used by the authors referenced in our study. It has been suggested that regular sampling along time may lead to a significant number of concentration data falling in the low range or below detection limits, whereas event-triggering sampling designs are more adequate to successfully detect short-term exposure peaks (Stehle et al. 2013). The highest environmental concentrations registered in the Arrecifes-Paraná basins in the northeast zone of the Pampa Húmeda region were associated with crop proximity and pesticide spraying sometimes followed by rain events (Marino and Ronco 2005). Similarly, the highest chlorpyrifos levels in the Tres Arroyos-Claromecó basin in the southeastern Pampa Húmeda corresponded with product applications to winter cultivars of wheat and barley and summer soybean cultivars close to the sampled streams (Álvarez 2015). The presence of peak concentrations of pesticide in water during the application season may have a higher impact on the aquatic biota than that predicted from regular sampling monitoring programs. This has been suggested for organophosphate pesticides, after their detected water levels were compared with observed biota biomarker responses that denote exposure to peak concentration levels (Rosenbaum et al. 2012).

Most of the samples in the Pampa Húmeda region were not in compliance with WQC; the chlorpyrifos concentrations fell within the range reported for other regions in Argentina. These include fruit-producing areas in irrigated valleys in the Patagonia region (Macchi et al. 2018), and sugarcane- and

TABLE 4: Comparison of environmental concentrations of chlorpyrifos in the Pampa Húmeda region with threshold effect concentrations for macroinvertebrate communities

\begin{tabular}{lcc}
\hline Endpoint or limit & Suggested or estimated concentration ( $\mu$ g/L) & Exceedance frequency (\%) \\
\hline NOEC ecosystem & 0.1 & 30.6 \\
Reviewed "micro/-mesocosm" NOEC & 0.1 & 30.6 \\
$0.05 \times$ EC50 most sensitive species (Daphnia magna) & 0.05 & 38.0 \\
$1 / 10$ EC50 Hyallela azteca & 0.01 & 56.5 \\
Threshold effects 1/1000 toxic units for Daphnia magna & 0.001 & 95.6 \\
\hline
\end{tabular}

${ }^{a}$ European Commission 2005; Brock et al. 2006

${ }^{b}$ Giddings et al. 2014.

'Van den Brink et al. 2002.

dHasenbein et al. 2016.

eSchäfer et al. 2012.

$\mathrm{NOEC}=$ no-observed-effect concentration; $\mathrm{EC50}=$ median effect concentration 
maize-producing areas in northern Tucumán province (De Gerónimo et al. 2014). We thus infer that lack of compliance with regulatory limits occurs throughout Argentina. Although information is still scarce, this concern appears to apply to other South American countries as well. Studies from Brazil and Chile report chlorpyrifos concentrations ranging from 0.01 to $0.04 \mu \mathrm{g} / \mathrm{L}$ (Barra et al. 1995; Albuquerque et al. 2016), that is, close to Pampa Húmeda median values. More reports on chlorpyrifos water levels in South American countries are clearly needed to properly assess its environmental risk on a continental scale.

Benthic macroinvertebrates have been recognized as the organisms most sensitive to many organic compounds, and consequently, have been mainly selected to build SSD curves and estimate HC5 values (Van den Brink et al. 2002). It has been suggested that although the composition of freshwater communities varies across biogeographical regions, climatic zones, and habitat types, the SSD does not vary markedly (Maltby et al. 2005). According to the chronic SSD developed in the present study, similar results are obtained if only macroinvertebrates or all aquatic species are selected. This is due to a superimposition of taxonomic groups such as aquatic insects, crustaceans, and fish in the high-sensitivity range (Figure 3B), which also explains a single log-normal distribution for the whole range.

In view of their sensitivity, macroinvertebrates have also been used to evaluate pesticide effects at the community level. Using diverse approaches encompassing macroinvertebrate assemblages, several limit values and criteria have been advanced to predict possible alterations (Van den Brink et al. 2002; European Commission 2005; Van Wijngaarden et al. 2005; Schäfer et al. 2012; Giddings et al. 2014). In our analysis, only the most conservative threshold limit of 1/1000 toxic units for Daphnia magna (Schäfer et al. 2012) seems appropriate to be applied to chlorpyrifos data: the inferred limit value is on the order of $0.001 \mu \mathrm{g} / \mathrm{L}$, which is close to the chronic HC5 calculated from the macroinvertebrate SSD. Accordingly, it was suggested that the NOEC for community-level effects is below the HC5 for crustaceans as the most sensitive taxa (Giddings et al. 2014). Taking together the chronic HC5 and the estimated threshold value for communitylevel effects in crustaceans, it seems reasonable to propose $0.7 \mathrm{ng}$ chlorpyrifos/L as a limit criterion to protect aquatic species from long-term exposures.

Because the 0.001- $\mu \mathrm{g} / \mathrm{L}$ threshold limit value for macroinvertebrate community effects is exceeded by a high percentage of environmental samples in the Pampa Húmeda, it is relevant to analyze the actual impact on benthic macroinvertebrates in the field. Several articles report mortality rates between 30 and 100\% for the amphipod Hyalella curvispina in streams contaminated with chlorpyrifos (Jergentz et al. 2004; Mugni et al. 2011). Benthic communities exposed to seasonal contamination show an increase in the abundance of tolerant taxa, Chironomidae and Oligochaeta, and a decrease in the more sensitive taxa, Ephemeroptera and Odonata (Crettaz et al. 2014). Changes in the structure of the aquatic invertebrate community are correlated with insecticide concentrations in streams at Pampa Húmeda, where amphipods from the genus Hyalella are among the most sensitive taxa (Hunt et al. 2017). Macchi et al. (2018) report a negative impact of chlorpyrifos on macroinvertebrate assemblage that correlates with peak concentrations of the insecticide during the application period in the Alto Valle de Río Negro in Argentina. They report a decrease in macroinvertebrate abundance and taxon richness associated with a decrease in the sensitive taxon Betidae and an increase in some tolerant taxa such as Chironomidae and Gastropoda. On the other hand, the development of tolerant populations of $\mathrm{H}$. curvispina has been reported in the same region as an adaptive response to organophosphorus pesticides and other contaminants (Anguiano et al. 2014; Del Brio et al. 2018).

Although field studies on macroinvertebrate communities consistently attest to the negative impact of chlorpyrifos and other pesticides in the Pampa Húmeda region, the recovery potential of affected biota also needs to be assessed. As evidence shows, macroinvertebrate communities can recover after repeated exposures to pesticides due to upstream unimpaired sources supplying migrating invertebrates to recolonize affected areas (Albariño et al. 2007). This kind of assessment, as well as ensuring compliance to agrochemical use regulations, should help prevent or mitigate potentially serious ecological imbalances resulting from species displacement, substitutions, and adaptations caused by overuse of chlorpyrifos and other pesticides in the Pampa Húmeda region.

Supplemental Data-The Supplemental Data are available on the Wiley Online Library at DOI: 10.1002/etc.4441.

Acknowledgment-We acknowledge the Consejo Nacional de Investigaciones Científicas y Técnicas and the Universidad de Buenos Aires (UBACYT 2010) for financial support. We are indebted to the reviewers and the Editor of Environmental Toxicology \& Chemistry for their valuable comments that improved the manuscript. We thank C. Lascano for English style revision. Present address for M. Alvarez and C. Du Mortier is Universidad Nacional de Moreno, Av. Bartolomé Mitre 1891, Moreno, Buenos Aires, Argentina.

Data Accessibility—Data, associated metadata, and calculation tools are available from the corresponding author (aventu1@yahoo.com.ar).

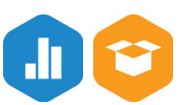

This article has earned an Open Data/Materials badge for making publicly available the digitally shareable data necessary to reproduce the reported results. The data are available on FigShare. Learn more about the Open Practices badges from the Center for Open Science: https://osf.io/tvyxz/wiki.

\section{REFERENCES}

Albariño R, Venturino A, Montagna CM, Pechen, de D'Angelo AM. 2007. Environmental effect assessment of Magnacide $\mathrm{H}$ herbicide at Río Colorado irrigation channels (Argentina). Tier 4: In situ survey on benthic invertebrates. Environ Toxicol Chem 26:183-189.

Albuquerque AF, Ribeiro JS, Kummrow F, Nogueira AJA, Montagner CC, Umbuzeiro GA. 2016. Pesticides in Brazilian freshwaters: A critical review. Environ Sci Process Impacts 18:779-787. 
Álvarez M. 2015. Estudios tendientes a establecer el comportamiento ambiental del insecticida clorpirifos en ambientes acuáticos de Tres Arroyos, Provincia de Buenos Aires. Universidad de Buenos Aires, Buenos Aires, Argentina. [cited 2019 March 15]. Available from. http://citaac. uncoma.edu.ar/index.php/component/phocadownload/category/10produccion-cientifica?download=17:estudios-tendientes-a-establecerel-comportamiento-ambiental-del-insecticida-clorpirifos-en-ambientesacuaticos-de-tres-arroyos-provincia-de-buenos-aires

Anguiano OL, Castro C, Venturino A, Ferrari A. 2014. Acute toxicity and biochemical effects of azinphos methyl in the amphipod Hyalella curvispina. Environ Toxicol 29:1043-1053.

Barra R, Vighi M, Di Guardo A. 1995. Prediction of surface water input of chloridazon and chlorpyrifos from an agricultural watershed in Chile. Chemosphere 30:485-500.

Bonansea RI, Amé MV, Wunderlin DA. 2013. Determination of priority pesticides in water samples combining SPE and SPME coupled to GCMS. A case study: Suquía River basin (Argentina). Chemosphere 90:1860-1869.

Brock TC, Arts GH, Maltby L, Van, den Brink PJ. 2006. Aquatic risks of pesticides, ecological protection goals, and common aims in european union legislation. Integr Environ Assess Manag 2:e20-e46.

California Department of Fish and Game. 2002. Water quality criteria for diazinon and chlorpyrifos. Sacramento, CA, USA. [cited 2019 March 15]. Available from: http://www.krisweb.com/biblio/cal_cdfg_siepmannetal_ 2000.pdf

Campbell PJ, Arnold DJS, Brock TCM, Grandy NJ, Heger W, Heimbach F, Maund SJ, Streloke M. 1999. Guidance document on higher-tier aquatic risk assessment for pesticides (HARAP). SETAC-Europe, Brussels, Belgium.

Canadian Council of Ministers for the Environment. 2008. Canadian water quality guidelines for the protection of aquatic life: Chlorpyrifos. Toronto, ON, Canada. [cited 2019 March 15]. Available from: http:// cegg-rcqe.ccme.ca/download/en/164?redir=1552488723

Cámara de Sanidad Agropecuaria y Fertilizantes. 2012. Mercado Argentino de productos fitosanitarios 2012. Buenos Aires, Argentina. [cited 2019 March 13]. Available from: https://www.casafe.org/pdf/2015/ ESTADISTICAS/Informe-Mercado-Fitosanitario-2012.pdf

Cámara de Sanidad Agropecuaria y Fertilizantes. 2016. El mercado de agroquímicos se mantuvo estable respecto de 2015. Buenos Aires, Argentina. [cited 2019 March 13]. Available from. https://www.casafe. org/pdf/2018/ESTADISTICAS/Informe-Mercado-Fitosanitarios-2016.pdf

Crettaz M, Juárez R, Aguer I, Borro E. 2014. Aplicación de índices de calidad de agua en un arroyo pampeano utilizando macroinvertebrados bentónicos como bioindicadores. Biol Acuát 30:93-105.

De Gerónimo E, Aparicio VC, Bárbaro S, Portocarrero R, Jaime S, Costa JL. 2014. Presence of pesticides in surface water from four sub-basins in Argentina. Chemosphere. 107:423-431.

Del Brio J, Montagna CM, Lares BA, Parolo ME, Venturino A. 2018. Chemical characterization and toxicity of water-accommodated fraction of oil on the South American native species Hyalella curvispina. Environ Toxicol Pharmacol 60:209-215.

Demetrio PM. 2012. Estudio de efectos biológicos de plaguicidas utilizados en cultivos de soja RR y evaluación de impactos adversos en ambientes acuáticos de agroecosistemas de la región pampeana. PhD thesis. Facultad de Ciencias Exactas, Universidad Nacional de La Plata, La Plata, Argentina. [cited 2019 march 20]. Available from: http://sedici.unlp.edu. ar/handle/10915/18139

Direction Générale de la Santé et des Consommateurs, European Commission. 2002. Guidance document on aquatic ecotoxicology in the context of the Directive 91/414/EEC. Health \& Consumer Protection DirectorateGeneral, SANCO/3268/2001 rev. 4 (final). Brussels, Belgium. [cited 2019 March 15]. Available from: https://yosemite.epa.gov/oa/EAB_Web_ Docket.nsf/Attachments\%20By\%20ParentFilingld/7B39B959EEFC9DEE85257FD20046C85C/\$FILE/PBNX\%20047.pdf

Ecological Committee on Federal Insecticide, Fungicide, and Rodenticide Act Risk Assessment Methods, US Environmental Protection Agency. 1999. Terrestrial draft report. Washington, DC. [cited 2019 March 15]. Available from: https://www.epa.gov/sites/production/files/2015-08/ documents/terrreport.pdf

European Commission. 2005. Common implementation strategy for the Water Framework Directive. Environmental quality standards (EQS) substance datasheet. Priority substance no. 9, chlorpyrifos. CAS no. 2921-88-2. Brussels, Belgium. [cited 2019 March 16]. Available from: https://circabc.europa.eu/sd/d/b19baa2f-04e6-4c23-ab426723712c0c90/09_Chlorpyrifos_EQSdatasheet_150105.pdf
European Commission. 2013. Directive 2013/39/EU of the European Parliament and of the Council of 12 August 2013 amending Directives 2000/60/EC and 2008/105/EC as regards priority substances in the field of water policy. Text with EEA relevance-EUR-Lex-Europa EU. Brussels, Belgium. [cited 2019 March 15]. Available from: https://eur-lex.europa. eu/legal-content/en/ALL/?uri=CELEX\%3A32013L0039

Giddings JM, Williams WM, Solomon KR, Giesy JP. 2014. Risks to aquatic organisms from use of chlorpyrifos in the United States. In Giesy JP, Solomon KR, eds, Ecological Risk Assessment for Chlorpyrifos in Terrestrial and Aquatic Systems in the United States, Vol 231-Reviews of Environmental Contamination and Toxicology. Springer, New York, NY, USA. pp 119-162.

Giesy JP, Solomon KR, Coats JR, Dixon KR, Giddings JM, Kenaga EE. 1999. Chlorpyrifos: Ecological risk assessment in North American aquatic environments. Rev Environ Contam Toxicol 160:1-129.

Hasenbein S, Lawler SP, Geist J, Connon RE. 2016. A long-term assessment of pesticide mixture effects on aquatic invertebrate communities. Environ Toxicol Chem 35:218-232.

Hunt L, Bonetto C, Marrochi N, Scalise A, Fanelli S, Liess M, Lydy MJ, Chiu M-C, Resh VH. 2017. Species at Risk (SPEAR) index indicates effects of insecticides on stream invertebrate communities in soy production regions of the Argentine Pampas. Sci Total Environ 580:699-709.

International Union of Pure and Applied Chemistry. 2019. Chlorpyrifos (Ref: OMS 971). Record last updated 2019 Jan 24. Zurich, Switzerland. [cited 2019 March 12]. Available from: https://sitem.herts.ac.uk/aeru/iupac/ Reports/154.htm

Jergentz S, Pessacq P, Mugni H, Bonetto C, Schulz R. 2004. Linking in situ bioassays and population dynamics of macroinvertebrates to assess agricultural contamination in streams of the Argentine pampa. Ecotoxicol Environ Safe 59:133-141.

Jergentz S, Mugni H, Bonetto C, Schulz R. 2005. Assessment of insecticide contamination in runoff and stream water of small agricultural streams in the main soybean area of Argentina. Chemosphere 61:817-826.

Macchi P, Loewy RM, Lares B, Latini L, Monza L, Guiñazú N, Montagna CM. 2018. The impact of pesticides on the macroinvertebrate community in the water channels of the Río Negro and Neuquén Valley, North Patagonia (Argentina). Environ Sci Pollut Res 25:10668-10678.

Maltby L, Blake N, Brock TCM, van den Brink PJ. 2005. Insecticide species sensitivity distributions: Importance of test species selection and relevance to aquatic ecosystems. Environ Toxicol Chem 24:379-88.

Marino D, Ronco A. 2005. Cypermethrin and chlorpyrifos concentration levels in surface water bodies of the Pampa Ondulada, Argentina. Bull Environ Contam Toxicol 75:820-826.

Mugni H, Ronco A, Bonetto C. 2011. Insecticide toxicity to Hyalella curvispina in runoff and stream water within a soybean farm (Buenos Aires, Argentina). Ecotoxicol Environ Safety 74:350-354.

Palumbo AJ, TenBrook PL, Fojut TL, Faria IR, Tjeerdema RS. 2012. Aquatic life water quality criteria derived via the UC Davis method: I. Organophosphate insecticides. In Tjeerdema RS, ed, Aquatic Life Water Quality Criteria for Selected Pesticides, Vol 216-Reviews of Environmental Contamination and Toxicology. Springer Science Business Media, New York, NY, USA. pp 1-49.

Pérez DJ, Okada E, De Gerónimo E, Menone ML, Aparicio VC, Costa JL. 2017. Spatial and temporal trends and flow dynamics of glyphosate and other pesticides within an agricultural watershed in Argentina. Environ Toxicol Chem 36:3206-3216.

Ronco A. 2015. Algunas respuestas sobre los impactos del uso de plaguicidas para el control de plagas en agroecosistemas de la región pampeana. Ciencia Invest 65:63-71.

Rosenbaum EA, Duboscq L, Soleño J, Montagna CM, Ferrari A, Venturino A. 2012. Response of biomarkers in amphibian larvae to in situ exposures in a fruit-producing region in North Patagonia, Argentina. Environ Toxicol Chem 31:2311-2317.

Rótolo GC, Montico S, Francis CA, Ulgiati S. 2014. Performance and environmental sustainability of cash crop production in Pampas Region, Argentina. J Environ Account Manag 2:229-256.

Schäfer RB, Von Der Ohe PC, Rasmussen J, Kefford BJ, Beketov MA, Schulz $R$, Liess M. 2012. Thresholds for the effects of pesticides on invertebrate communities and leaf breakdown in stream ecosystems. Environ Sci Technol 46:5134-5142.

Solomon KR, Baker DB, Richards RP, Dixon KR, Klaine SJ, La Point TW, Kendall RJ, Weisskopf CP, Giddings JM, Giesy JP, Hall LW, Williams 
WM. 1996. Ecological risk assessment for atrazine in North American surface waters. Environ Toxicol Chem 15:31-76.

Stehle S, Knäbel A, Schulz R. 2013. Probabilistic risk assessment of insecticide concentrations in agricultural surface waters: A critical appraisal. Environ Monit Assess 185:6295-6310.

Subsecretaría de Recursos Hídricos de la Nación. 2005. Desarrollos de niveles guía nacionales de calidad de agua ambiente correspondientes a clorpirifos. Buenos Aires, Argentina. [cited 2019 March 15]. Available from:. https://www.mininterior.gov.ar/obras-publicas/pdf/DOCUMENTO35.pdf

US Environmental Protection Agency. 1986. Ambient water quality criteria for chlorpyrifos. Washington, DC. [cited 2019 March 15]. Available from: https://nepis.epa.gov/Exe/ZyPDF.cgi/2000M58T.PDF?Dockey= 2000M58T.PDF

US Geological Survey. 2000. Organophosphorus pesticide occurrence and distribution in surface and ground water of the United States, 1992-97. National Water-Quality Assessment (NAWQA) Program and National,
Stream Quality Accounting Network (NASQAN), Reston, VA, USA. [cited 2019 March 12]. Available from: http://pubs.usgs.gov/of/2000/ofr00-187/ pdf/ofrO0-187.pdf

Van den Brink PJ, Hartgers EM, Gylstra R, Bransen F, Brock TCM. 2002. Effects of a mixture of two insecticides in freshwater microcosms: II. Responses of plankton and ecological risk assessment. Ecotoxicology 11:181-197.

Van Wijngaarden RPA, Brock TCM, Van den Brink PJ. 2005. Threshold levels for effects of insecticides in freshwater ecosystems: A review. Ecotoxicology 14:355-380.

Williams WM, Giddings JM, Purdy J, Solomon KR, Giesy JP. 2014. Exposures of aquatic organisms to the organophosphorus insecticide, chlorpyrifos resulting from use in the United States. In Giesy JP, Solomon KR, eds, Ecological Risk Assessment for Chlorpyrifos in Terrestrial and Aquatic Systems in the United States, Vol 231-Reviews of Environmental Contamination and Toxicology. Springer, New York, NY, USA. pp 77-117. 